e-ISSN: 2776-222X

Vol. 1(2) 2021, pp. 123 - 132

\title{
Task-based language teaching methods integrated with local wisdom: The impact on students' writing skills
}

\author{
Balqis Husain, Suhernita Suhernita, Zulhasmi Abasa, Fahmi Djaguna* \\ Universitas Pasifik Morotai, Indonesia
}

\begin{abstract}
The researcher conducts the study to increase students' writing skills through TBLT (Task-Based Language Teaching). The subject of this research consists of 32 students in the VIII A class. The objectives of this research are categorized into 2; (1) to find out whether the implementation of the Task-Based Learning method can improve the students' writing skills, and (2) to find out what kind of writing aspects improve significantly after using Task-Based Learning method. Research design uses pre-test and post-test. Therefore, both groups are given a pre-test, conduct a treatment, then pass a post-test. This research is conducted at eighth grade in 2019/2020 for one month, from August to September 2020. This research shows that after being taught task-based language teaching, students' writing skills, especially in narrative text, improved substantially. It can be analyzed on post-test performance; no one has reached the excellent, good, and fair categories (0 percent). 37.5 percent of students have reached the appropriate category. 65.2 percent of students had failed in the category unless they had handled it for seven meetings. This result is slightly different from the pre-test result. However, only 25 percent of students fall into the decent category, and 75 percent fail. There are no students who are in weak, moderate, decent, and outstanding categories.
\end{abstract}

Keywords: Task-based language teaching methods, local wisdom, writing skills

\section{Metode pengajaran bahasa berbasis tugas yang terintegrasi dengan kearifan lokal: Dampaknya pada keterampilan menulis siswa}

\begin{abstract}
Abstrak: Peneliti melakukan penelitian untuk meningkatkan keterampilan menulis siswa melalui TBLT (Task-Based Language Teaching). Subjek penelitian ini berjumlah 32 siswa di kelas VIII A. Tujuan penelitian ini dikategorikan menjadi 2; (1) untuk mengetahui apakah penerapan metode Task-Based Learning dapat meningkatkan keterampilan menulis siswa, dan (2) untuk mengetahui aspek menulis apa saja yang meningkat secara signifikan setelah menggunakan metode Task-Based Learning. Desain penelitian menggunakan pre-test dan post-test. Oleh karena itu, kedua kelompok diberikan pre-test, melakukan treatment, kemudian lulus post-test. Penelitian ini dilakukan di kelas delapan tahun 2019/2020 selama satu bulan, dari Agustus hingga September 2020. Penelitian ini menunjukkan bahwa setelah diajarkan pengajaran bahasa berbasis tugas, keterampilan menulis siswa, terutama dalam teks naratif, meningkat secara substansial. Hal ini dapat dianalisis pada kinerja post-test; belum ada yang mencapai kategori sangat baik, baik, dan cukup ( 0 persen). 37,5 persen siswa sudah mencapai kategori sesuai. 65,2 persen siswa gagal dalam kategori tersebut kecuali mereka telah menanganinya selama tujuh kali pertemuan. Hasil ini sedikit berbeda dengan hasil pre-test. Namun, hanya 25 persen siswa yang masuk dalam kategori layak, dan 75 persen gagal. Tidak ada siswa yang termasuk dalam kategori lemah, sedang, layak, dan luar biasa.
\end{abstract}

Kata Kunci: Metode pengajaran bahasa berbasis tugas, kearifan lokal, keterampilan menulis

Received: 28-11-2021

Accepted: 15-12-2021
To cite this article: Husain, B., Suhernita, S., Abasa, Z., \& Djaguna, F. (2021). Task-based language teaching methods integrated with local wisdom: The impact on students' writing skills. Journal of Research in Instructional, 1(2), 123-132. https://doi.org/10.30862/jri.v1i2.22

*Corresponding author: fahmidjaguna.morotai@gmail.com 


\section{INTRODUCTION}

English is seen as a language that is the capital for humans to communicate with the wider world. Writing a coherent and unity English paragraph requires writing skills (Wali \& Madani, 2020). Writing is a key ability to have while studying English. It has always been included in the majority of English language courses. To write properly, kids must possess strong writing skills. Additionally, anyone wishing to write an essay or a tale should be familiar with the writing process and many parts of writing. The writer must arrange his or her thoughts, form sentences, and ensure proper grammar and spelling. Additionally, learners should be able to organize their work into meaningful paragraphs and sentences. Apart from other language skills, writing is one that should be taught. Writing is seen as a constructive talent; it tries to help learners in verbally expressing their thoughts. Writing is a sophisticated technique of communication. The students may choose a word or phrase and then reassemble it into a valid sentence and an excellent sentence. This writing ability includes an understanding of proper grammar, capitalization, and spelling. The writing lesson often begins with the creation of a sentence, progresses to the development of a sentence into a passage, and concludes with the creation of a paper.

According to Powell (Powell, 2009), writing is difficult to notice because it directs our thinking and difficult to discuss since genuine categories lack consistent labels. Writing is a notational system with a fixed reference that conveys information, such as the signs on this page. Writing is a difficult task for the majority of individuals, whether in their own language or a foreign one. Writing is the most difficult talent to master in comparison to the other three. Placing letters, symbols, and numbers requires a variety of skills, including paragraph construction, mechanics, and content organization, as well as conventional grammar, syntax, and vocabulary. Writing is a more difficult ability to master than other abilities. Writing ability is the ability to organize and generate written form in an orderly and accurate manner on the linguistic component. The components of writing include vocabulary, sentence structure, sentence construction, spelling, and punctuation. These are critical skills to learn in order to generate quality writing.

Based on the researcher's observation at MTs. Negeri 1 Pulau Morotai, the researcher, found some problems in teaching and learning English. Most students still did not know how to compose sentences, build the paragraphs, or make a sentence because producing the words was limited. When students do the teacher's assignments related to the writing class, they do not have an interest in the lesson, so that the value can be even less satisfying. Sometimes, the researcher investigates the most difficult words to produce words when they give them some exercises. Furthermore, the researcher also found that some students were sleepy in the classroom during the lesson. Most of the students thought that writing class is boring because the teacher taught them rather monotonous and they were not well motivated to practice their writing skills. They were no interaction or response of the students about the material from their teacher.

Writing is a skill that is quite difficult for students learning a second language (Istiara \& Lustyantie, 2017). By learning to write students will be more skilled in developing various ideas they have into written form (Pujiastuti, 2016), through the writing skills students have, they can translate their creative ideas into writing so that readers can communicate with the author (Fitri, 2016). Students' difficulties in writing must be solved by the teacher through the right strategy (Astrini et al., 2020). Initial research found by Murtiningrum et 
al. (2020) found that only a few students (23\%) were able to succeed in writing English letters. They fix the problems that occur by implementing Task-Based Language Teaching (TBLT). The results of their research show that TBLT can improve students' writing skills with student achievement as much as $97 \%$. Another research by Rahayu \& Achaliyah (2020) found that TBLT in non-English classes with foreign language writing assignments made students' correspondence skills increase.

English learning can be improved by using TBLT (Phuong, 2018). Teachers must design writing assignments for their students so that they can empower students' English communicative skills (Yen, 2016). A review by Wang Chong and Reinders (2020) found that students experienced an increase in language skills after they participated in TBLT. In their review, they stated that the improvement in students' language skills was because they practiced the target language being studied. The tasks given in TBLT are predominantly contextual based. TBLT is successful for Asian students by paying attention to the local environment and using it to set up a contextual-based learning environment (Butler, 2011). Enriching and maintaining the authenticity of learning resources in TBLT by presenting contextual learning (Chen \& Wright, 2017). In Chen and Wright, (2017), the contextual process is carried out by connecting the real world and authentic material into student discussions in teacher-led learning. Students become communicative and can make their reports well. The challenge for teachers in EFL classes is to create authentic nuances based on the real-life context of learners (Luo \& Gong, 2015).

One of the challenges teachers face in implementing and contextualizing TBLT is managing the level of authentic 'tasks' in their teaching practice (Littlewood, 2011; Shehadeh, 2012). Contextual-based learning by utilizing the surrounding environment can improve student performance (Bhure et al., 2021; Lelasari et al., 2021; Ruto et al., 2021). Contextual problems can be adapted from local wisdom. Local wisdom is a perspective on life and science, as well as a variety of living tactics expressed via the actions of the local community in response to different situations and in addressing their needs. According Permana, (2010) indigenous knowledge is often connected with indigenous cultures. Local wisdom is sometimes misinterpreted in other languages as local knowledge, local intelligence, or local wisdom. These three concepts define the concept of culture that has been passed down from generation to generation for hundreds, if not thousands, of years by indigenous or indigenous people. Local knowledge with deep roots is less susceptible to being affected and corrupted by other civilizations. Learning that is integrated with local potential fosters student skills (Damopolii et al., 2019; Nusantari et al., 2020)

The objectives of this research are categorized into 2; (1) to find out whether the implementation of the Task-Based Learning method can improve the students' writing skills, and (2) to find out what kind of writing aspects improve significantly after using TaskBased Learning method.

\section{METHOD}

The design in this research used quantitative research and focused on the preexperimental method. This research tried to describe using the Task-Based Language Teaching (TBLT) method to develop students' writing skills, especially in writing narrative text. The research design was to use pre-test and post-test. Therefore, both groups were given a pre-test, conduct a treatment then give a post-test. 
This research was conducted at eighth grade in 2019/2020 for one month, from October to November 2020. This research was taken place in Mts. Negeri 1 Pulau Morotai.

The variable in this research included two variables, namely, the independent variable and the dependent variable. Task-Based Language Teaching (TBLT) technique (variable X) was the independent variable; the students' improvement in writing skill was the dependent variable (variable Y).

The population was thought of as all people, events, or things that fit into a certain category. A population can be a very large group of people. In this study, the researcher took the population of the eighth grade at Mts. Negeri 1 Pulau Morotai, which was made up of five groups. The total number of students was 200 . Because the population was too big, the researcher needed to pick a small group to study. The sample was a small part of the population. Here, the researcher only looked at eighth-graders, which is VIII B class. 16 males and 16 females took this class, which had 32 learner.

To obtain the data, the researcher used two techniques. Therefore, the researcher conducted the TBLT and writing test. This test could be explained as follow:

1. The Researcher Explained the TBLT method to the students.

2. The Researcher implemented a narrative text to improve students' writing skills.

3. The Researcher prepared one local wisdom legend for students' to be analyzing the students' scores about the narrative text in writing from the experimental group.

4. The time used was 30 minutes to pre-test and 45 minutes to post-test, one local wisdom legend.

The researcher scored the students' writing test covering writing components such as content, organization, vocabulary, language feature, and mechanics. In scoring the students' answers, five aspects were assessing. They are content, organization, vocabulary, language feature, and mechanics.

Scoring the students:

$$
\text { Score } \frac{\text { Raw score }}{\text { The maximal score }} \times 100
$$

The researcher determined the conversation of the students' writing skill based on the following:

Table 1. Category of writing skill

\begin{tabular}{ccc}
\hline No & Score Range & Category \\
\hline 1. & $86-100$ & Very Good \\
\hline 2. & $71-85$ & Good \\
\hline 3. & $56-70$ & Moderate \\
\hline 4. & $<55$ & Low \\
\hline & & (Depdiknas, 2011)
\end{tabular}

\section{RESULTS}

To Identify the Students' improvement after implemented TBLT Method. Several tables were presented on this point, score range and percentage of pre-test and post-test table can be seen on the table 2 . 
Table 2. Score range and percentage of pre-test and post-test

\begin{tabular}{cccccc}
\hline Range & Interpretation & Pre-test & Percentage & Post-test & Percentage \\
\hline $80-100$ & Excellent & 0 & $0 \%$ & 0 & $0 \%$ \\
\hline $70-79$ & Good & 0 & $0 \%$ & 0 & $0 \%$ \\
\hline $60-69$ & Fair & 0 & $0 \%$ & 0 & $0 \%$ \\
\hline $40-59$ & Poor & 8 & $25 \%$ & 12 & $37.5 \%$ \\
\hline $0-39$ & Fail & 24 & $75 \%$ & 20 & $62.5 \%$ \\
\hline & Total & 32 & $100 \%$ & 32 & $100 \%$ \\
\hline
\end{tabular}

The table showed that after being taught task-based language teaching, the students improved writing skills, especially in narrative text, had increased substantially. It can be analyzed on the post-test performance; no one has reached an outstanding, good, and fair category ( 0 percent). 37.5 percent of students have achieved an appropriate category. 65.2 percent of students have failed in the category unless they have been handled for seven meetings. This outcome was slightly different from the pre-test result. However, only 25 percent of students were in the appropriate category, and 75 percent of students failed, and nobody was in the weak, fair, decent, and excellent category.

Table 3. Descriptive statistics

\begin{tabular}{lccccc}
\hline & N & Minimum & Maximum & Mean & SD \\
\hline Pre-test & 32 & 20 & 48 & 28.38 & 9.711 \\
\hline Post-test & 32 & 20 & 52 & 31.50 & 10.045 \\
\hline Valid N & 32 & & & & \\
\hline
\end{tabular}

The data indicated that the sample number $(\mathrm{N})$ was 32 students. The mean students score for the post-test was slightly higher than the mean for the pre-test. The mean posttest was 31.50 and the mean pre-test was 28.38. While, Std. deviation of post-test was 10.045 a little higher than std. Deviation from the pre-test (9.711). The maximum post-test score was determined to be 52; it was higher compared to the maximum pre-test score (48). Either the pre-test or post-test had a similar minimum score of 20.

Table 4. Tests of normality

\begin{tabular}{llcccccc}
\hline \multirow{2}{*}{ Class } & \multicolumn{3}{c}{ Kolmogorov-Smirnova } & \multicolumn{3}{c}{ Shapiro-Wilk } \\
\cline { 3 - 8 } & & Statistic & df & Sig. & Statistic & Df & Sig. \\
\hline \multirow{2}{*}{ Result } & Pre-test & 0.275 & 32 & .000 & 0.803 & 32 & 0.000 \\
\cline { 2 - 8 } & Post-test & 0.147 & 32 & .075 & 0.904 & 32 & 0.008 \\
\hline
\end{tabular}

This research sample achieved more than 30 students, so the researcher used the Kolmogorov-Smirnov test for conducting the normality test. The pre-test and post-test data were not usually distributed; whereas the sig. Value of the pre-test $(0.000)$ was lower than 0.05 . In contrast, the post-test data was 0.075 , less than 0.05 . it was assumed that the data would not normally be spread. 
Table 5. Ranks test

\begin{tabular}{lllcc}
\hline & & \multicolumn{2}{c}{ N } & Mean Rank Sum of Ranks \\
\hline Post_test - Pre_test & Negative Ranks & $0^{\mathrm{a}}$ & 0.00 & 0.00 \\
\cline { 2 - 5 } & Positive Ranks & $14^{\mathrm{b}}$ & 7.50 & 105.00 \\
\cline { 2 - 5 } & Ties & $18^{\mathrm{c}}$ & & \\
\cline { 2 - 5 } & Total & 32 & & \\
\hline
\end{tabular}

It can be analyzed that the Negative, Mean, and Sum values were 0 so that no reduction was observed between the pre-test and the post-test. However, positive rank data demonstrated that 14 students enhanced their written ability by measuring the pre-test and post-test scores. The mean rank was 7.50, and the sum of ranks was 105. 00. 00. The tie score was 18 , so its equal value was determined before and after the test.

Table 6. Wilcoxon Signed Rank Test

\begin{tabular}{lr}
\hline & Post_test - Pre_test \\
\hline$Z$ & -3.359 a \\
\hline Asymp. Sig. (2-tailed) & 0.001 \\
\hline
\end{tabular}

The statistics revealed Symp. Sig. Sig. (2-taied) was $0.001(\mathrm{p}>0.05)$. It meant that Hypothesis Nul (HO) was dismissed, and the alternative (Ha) hypothesis was accepted. It can be inferred that the TBLT method has motivated students to develop their writing skills, mostly in narrative text.

Table 7. Indicators of writing

\begin{tabular}{llccccc}
\hline No & $\begin{array}{c}\text { Indicators of } \\
\text { Writing }\end{array}$ & $\mathbf{N}$ & Minimum & Maximum & Mean & SD \\
\hline 1 & Content & 32 & 8 & 11 & 8.53 & .803 \\
\hline 2 & Organization & 32 & 8 & 14 & 10.47 & 1.107 \\
\hline 3 & Vocabulary & 32 & 4 & 6 & 4.78 & 0.706 \\
\hline 4 & Language Feature & 32 & 4 & 5 & 4.22 & 0.420 \\
\hline 5 & Mechanism & 32 & 6 & 9 & 6.81 & 1.030 \\
\hline & Total & 32 & 30 & 45 & 34.81 & 4.066 \\
\hline
\end{tabular}

The table revealed five measurements were used in writing; content, organization, vocabulary, figurative language, and mechanism. The questionnaire was calculated by a Likert scale, which ranged from 1) complete disagreement; 2) disagreement; 3) doubtfulness; 4) agreement; and 5) total agreement. From the table above, the study observed that the Task-Based Language Teaching (TBLT) method forced students to be good at writing, especially in the organizational aspect. The mean organization predictor was shown to be 10.47. The content aspect took second place with an 8.53 mean score, and the mechanism aspect reached third place with a 6.81 mean score, and both vocabulary and language features at the last position with 4.78 and 4.22 mean score. 
Table 8. Classification of writing skill

\begin{tabular}{lc}
\hline Score & Score Categorization \\
\hline $86-100$ & Very Good \\
\hline $76-85$ & Good \\
\hline $56-75$ & Moderate \\
\hline$<55$ & Low \\
\hline
\end{tabular}

Based on the classification of writing skill above, the researcher concluded that the respondents of this research have low level due to the total score falls within the range of 20 to 52 .

\section{DISCUSSION}

The aim of this present research is to find out the Utilization of TBLT method based on local wisdom to improve students' writing skill in narrative text at the eighth grade of Mts. Negeri 1 Pulau Morotai academic year 2020/2021 which is located at Gotalamo, Morotai Selatan. To identify the students' improvement after implemented TBLT method, in the table score range and percentage of pre-test and post test showed that after being taught TBLT, the students improved writing skills, especially in narrative text, had increased substantially. It can be analyzed on the post-test performance; no one has reached an outstanding, good, and fair category ( 0 percent). 37.5 percent of students have achieved an appropriate category. 65.2 percent of students have failed in the category unless they have been handled for seven meetings. This outcome was slightly different from the pre-test result. However, only 25 percent of students were in the appropriate category, and 75 percent of students failed, and nobody was in the weak, fair, decent, and excellent category.

To describe types of writing aspect that improve after conducting TBLT method, the table of accumulation writing aspects shows the accumulation of writing aspects score. The score fell within range 67 to 75.4 vocabulary score dominated than the others, and followed by mechanism aspects, language feature, organization, and content. Ahmed and Bidin (2016) conducted a research on the effect of TBLT on the writing skills of EFL students in Malaysia. The results of the study were published in 2016. The findings of the study reveal that Task Based Language Teaching has a statistically significant impact on students' writing abilities after they have received instruction. TBLT improves students' writing skills, especially writing descriptive text (Ardika et al., 2021). With TBLT students are encouraged to be active, help them communicate, provide authentic learning opportunities, and the ability to use a second language (Sholeh, 2020). TBLT fosters students' desire to learn to write, engage in learning and empower their writing skills (Yundayani \& Ardiasih, 2021).

Overall, when TBLT is implemented, students are compelled to communicate in person or via groups in order to complete their writing tasks. As a result, individuals have several chances to express their opinions, which helps to alleviate the problems associated with obtaining and organizing the information. In addition, the lecturer was continually encouraging and motivating the learnerls. Therefore, if students get bewildered throughout their steps, they may request help from their teacher as soon as they become aware of it. The students are the main subjects of the writing-learning process in which they are 
involved. They are also the primary subjects of the writing-learning process in which they are involved. The students are getting more and more active in the process. As a consequence, it has the potential to broaden their linguistic repertoire. It also improves the students' capacity to understand grammatical constructs and to utilize good mechanics while writing, both of which are important skills. Following completion of the TBLT stages, which comprise pre-task and linguistic concentration, the researchers discovered that students produced higher writing results (post-task). Also clear in their final writing, which was held at the end of each cycle, was that students had made great development in five areas of writing: vocabulary, organization, content, language use, and mechanics, all of which were evaluated. This shows that the strategy had a positive influence on their ability to write effectively. This not only increased students' writing results, but it also enhanced students' metacognitive skills as a consequence of their participation in the program. It is feasible to conclude from the above discussion that TBLT utilizing narrative text may aid students in the development of their writing abilities.

\section{CONCLUSION}

Based on the our finding and discussion, this research conclude that's there is the effect of TBLT on students writing narrative text. The data in the pre-test table and the posttest score showed that after being taught TBLT, the students improved writing skills, especially in narrative text, had increased substantially. It can be analyzed on the post-test performance; no one has reached an outstanding, good, and fair category ( 0 percent). 37.5 percent of students have achieved an appropriate category. 65.2 percent of students have failed in the category unless they have been handled for seven meetings. The study observed that the Task-Based Language Teaching (TBLT) method forced students to be good at writing, especially in the organizational aspect. The mean organization predictor was shown to be 10.47. The content aspect took second place with an 8.53 mean score, and the mechanical aspect reached third place with a 6.81 mean score, and both vocabulary and language features at the last position with 4.78 and 4.22 mean score.

\section{REFERENCES}

Ahmed, R. Z., \& Bidin, S. J. B. (2016). The Effect of task based language teaching on writing skills of efl learners in Malaysia. Open Journal of Modern Linguistics, 06(03), 207-218. https://doi.org/10.4236/ojml.2016.63022

Ardika, I. W. D., Ratminingsih, N. M., \& Artini, L. P. (2021). The implementation of task-based language teaching on project and creative task to improve writing skill. Elementary Education Online, 20(5), 67-72. https://doi.org/10.17051/ilkonline.2021.05.07

Astrini, F., N.M, R., \& G.A. L.P, Utami, I. (2020). The model of strategies employed by english teachers in teaching writing skill in National Plus Schools. Journal of Education Research and Evaluation, 4(1), 59-62. https://doi.org/10.23887/jere.v4i1.23682

Bhure, M., Welu, F., See, S., \& Ota, M. K. (2021). The effort to enhance pupils cognitive learning achievement using contextual teaching and learning approach. Journal of Research in Instructional, 1(1), 13-22. https://doi.org/10.30862/jri.v1i1.3

Butler, Y. G. (2011). The Implementation of communicative and task-based language teaching in the Asia-Pacific Region. Annual Review of Applied Linguistics, 31, 36-57. https://doi.org/10.1017/S0267190511000122 
Chen, Q., \& Wright, C. (2017). Contextualization and authenticity in TBLT: Voices from Chinese classrooms. Language Teaching Research, 21(4), 517-538. https://doi.org/10.1177/1362168816639985

Damopolii, I., Nunaki, J. H., Nusantari, E., \& Kandowangko, N. Y. (2019). Integrating local resources into inquiry-based teaching materials to training students' science process skills. AIP Conference Proceedings, 2120, 060003. https://doi.org/10.1063/1.5115703

Depdiknas, 2011. Pembinaan Pendidikan karakter di sekolah menengah pertama. Jakarta: Dirjend Dikdasmen.

Fitri, R. (2016). Penerapan teknik pemodelan untuk meningkatkan kemampuan menulis surat resmi siswa kelas VIII SMP. Gramatika: Jurnal Penelitian Bahasa Dan Sastra Indonesia, 2(2), 118-132. https://doi.org/10.22202/jg.2016.v2i2.1200

Istiara, F., \& Lustyantie, N. (2017). The influence of cooperatif learning model and critical thinking on essay writing skills (Experiment Study). World Journal of English Language, 7(2), 22-30. https://doi.org/10.5430/wjel.v7n2p22

Lelasari, T., Yohanita, A. M., \& Damopolii, I. (2021). Effect of inquiry science learning on students' metacognitive skill. Journal of Research in Instructional, 1(1), 53-60. https://doi.org/10.30862/jri.v1i1.12

Littlewood, W. (2011). Communicative language teaching: An Expanding concept for a changing world. In E. Hinkel (Ed.), Handbook of research in second language teaching and learning (Vol. 2, pp. 541-557). Taylor \& Francis.

Luo, S., \& Gong, Y. (2015). Exploring ways to accommodate task-based language teaching in Chinese schools. In M. Thomas \& H. Reinders (Eds.), Contemporary task-based language teaching in Asia. Bloomsbury.

Murtiningrum, R. C. R. D., Rafli, Z., \& Purbaini, A. (2020). Penerapan metode task-based learning untuk meningkatkan keterampilan menulis surat bisnis bahasa inggris. DEIKSIS, 12(220-228), 220. https://doi.org/10.30998/deiksis.v12i02.5026

Nusantari, E., Utina, R., Katili, A. S., Tamu, Y., \& Damopolii, I. (2020). Effectiveness of Environmentally-Based Science Learning towards Environmentally-Friendly Character of Students in Coastal Area. International Journal of Instruction, 13(3), 233246.

Permana, C. E. (2010). Kearifan Lokal Masyarakat Badui dalam Mitigasi Bencana. Wedatama Widya Sastra.

Phuong, T. H. C. (2018). Task-Based Language Teaching: Affordances and challenges in TBLT Implementation at the Vietnamese tertiary level. The Journal of AsiaTEFL, 15(2), 510-515. https://doi.org/10.18823/asiatefl.2018.15.2.19.510

Powell, H. (2009). Advertising agencies and their clients. In J. Hardy, I. Macrury, H. Powell, \& S. Hawkin (Eds.), The Advertising Handbook (3rd Editio). Routledge.

Pujiastuti, R. R. (2016). Efektifitas penggunaan model pembelajaran kooperatif dengan presentasi untuk meningkatkan kemampuan belajar menulis surat kelas XI PM di SMK Negeri 48. Jurnal Ilmiah Econosains, 14(2), 55-61. https://doi.org/10.21009/econosains.014.2.6

Rahayu, B. S., \& Achaliyah, S. (2020). Metode task based learning bahasa inggris dan bahasa mandarin berpengaruh terhadap kemampuan korespondensi bahasa asing. Jurnal Administrasi Kantor, 8(2), 127-138. https://doi.org/10.51211/jak.v8i2.1447

Ruto, R., Mema, A., Nduru, M. P., \& Ota, M. K. (2021). Contextual teaching and learning 
approach in social science: its role to encourage pupils' cognitive learning achievement. Journal of Research in Instructional, 1(1), 43-52. https://doi.org/10.30862/jri.v1i1.11

Shehadeh, A. (2012). Introduction: Broadening the perspective of task-based language teaching scholarship: The contribution of research in foreign language contexts. In A. Shehadeh \& C. A. Coombe (Eds.), Task-based language teaching in foreign language contexts: Research and implementation (pp. 1-20). John Benjamins.

Sholeh, M. B. (2020). Implementation of task-based learning in teaching english in Indonesia: Benefits and problems. Language Circle: Journal of Language and Literature, 15(1), 1-9. https://doi.org/10.15294/lc.v15i1.26004

Wali, O., \& Madani, A. Q. (2020). The Importance of paragraph writing: An introduction. international journal of latest research in humanities and social science, 3(7), 44-50.

Wang Chong, S., \& Reinders, H. (2020). Technology-mediated task-based language teaching: A qualitative research synthesis. Language Learning \& Technology, 24(3), 70-86. http://hdl.handle.net/10125/44739

Yen, P. H. (2016). Challenges of shifting to task-based language teaching: A story from a Vietnamese teacher. Can Tho University, Journal of Science, 2, 37-45. https://doi.org/10.22144/ctu.jen.2016.002

Yundayani, A., \& Ardiasih, L. S. (2021). Task-based material design for academic purposes: Learners' English writing skill improvement. Studies in English Language and Education, 8(1), 258-275. https://doi.org/10.24815/siele.v8i1.18169 